\title{
ОСОБЛИВОСТІ ПСИХОПАТОЛОГІЧНОЇ СИМПТОМАТИКИ У ХВОРИХ ІЗ ДЕПРЕСИВНИМИ РОЗЛАДАМИ
}

\section{Особливості психопатологічної симптоматики у хворих із депресивними розладами}

\section{О. О. Белов}

Вінницький національний медичний університет імені М. І. Пирогова

Резюме. Дослідження клінічної френоменології депресивних розладів має важливе значення для визначення напрямків сучасного патоморфозу, прогнозування та лікування депресій.

Мета дослідження - вивчити структуру і вираження психопатологічної симптоматики у хворих із депресивними розладами на сучасному етапі з урахуванням віку та гендерного орактора.

Матеріали і методи. Проведено клінічне обстеження 107 чоловіків і 138 жінок із депресивними розладами ендогенного характеру (коди за МКX-10 F 31.3, $F$ 31.4, F 32.0, F 32.1, F 32.2, F 33.0, F 33.1, F 33.2) 3 урахуванням віку та гендерного фрактора, з використанням опитувальника SCL-90-R.

Результати. Депресивні розлади, окрім депресивноі симптоматики, проявляються широким спектром психопатологічних проявів, серед яких домінують підвищені рівні тривожності - $(2,40 \pm 0,45)$ бала, помірні рівні міжособистісної сензитивності - $(1,73 \pm 0,48)$ бала та обсесивнокомпульсивної симптоматики - $(1,44 \pm 0,85)$ бала, близькі до помірних рівні соматизації - $(1,05 \pm 0,51)$ бала і фробічної тривожності - $(1,00 \pm 0,47)$ бала, а також невисокі рівні психотизму - $(0,64 \pm 0,24)$ бала, ворожості - $(0,55 \pm 0,77)$ бала $i$ паранояльної симптоматики - $(0,26 \pm 0,13)$ бала. У чоловіків виявлено значуще вищі показники депресії, ворожості й паранояльної симптоматики, а у жінок - тривожності, обсесивно-компульсивної симптоматики, міжособистісної сензитивності, соматизації та фробічної тривожності. Гендерні відмінності у вираженні психопатологічної симптоматики ймовірно пов'язані з різними статеворольовими моделями і специорікою гендернозумовлених патохарактерологічних змін. Вираження усіх психопатологічних проявів збільшується з віком, при цьому більш суттєве погіршення проявів психопатологічної симптоматики відбувається у віці 45 років і старше, тоді як зростання показників психопатологічної симптоматики у молодому віці виявилося менш суттєвим.

Висновки. Клінічна картина сучасних депресивних розладів характеризується поліморфністю симптоматики і наявністю значущих гендерних відмінностей; психопатологічні прояви посилюються з віком, дося-
Features of psychopathological symptoms in patients with depressive disorders

o. O. Belov

M. Pyrohov Vinnytsia National Medical University

e-mail: oleksbelov@gmail.com

Summary. The study of the clinical phenomenology of depressive disorders is important for determining the directions of modern pathomorphosis, prognosis and treatment of depression.

The aim of the study - to investigate the structure and severity of psychopathological symptoms in patients with depressive disorders at the present stage, taking into account age and gender factor.

Materials and Methods. A clinical examination of 107 men and 138 women with endogenous depressive disorders (ICD-10 codes $F$ 31.3, $F$ 31.4, $F$ 32.0, $F$ 32.1, $F$ 32.2, F 33.0, F 33.1, F 33.2), taking into account age and gender factor, using the questionnaire SCL-90-R was performed.

Results. Depressive disorders, in addition to depressive symptoms, are manifested by a wide range of psychopathological manifestations, among which are dominated by increased levels of anxiety $(2.40 \pm 0.45)$ points, moderate levels of interpersonal sensitivity $(1.73 \pm 0.48)$ points and obsessive-compulsive symptoms (1.44 \pm 0.85$)$ points, close to moderatelevels of somatization (1.05 \pm 0.51$)$ points and phobic anxiety $(1.00 \pm 0.47)$ points, as well as low levels of psychoticism $(0.64 \pm 0.24)$ points, hostility $(0.55 \pm 0.77)$ points and paranoid symptoms (0.26 \pm 0.13$)$ points. Significantly higher rates of depression, hostility and paranoid symptoms were found in men, and anxiety, obsessive-compulsive symptoms, interpersonal sensitivity, somatization and phobic anxiety were found in women. Gender differences in the severity of psychopathological symptoms are probably related to different gender role models and the specifics of genderbased pathocharacterological changes. The severity of all psychopathological manifestations increases with age, with a more significant deterioration in the manifestations of psychopathological symptoms occurs at the age of 45 years and older.

Conclusions. The clinical picture of modern depressive disorders is characterized by polymorphic symptoms and the presence of significant gender differences; and psychopathological manifestations intensify with age, reaching the greatest severity in middle-aged, elderly and 
гаючи найбільшого вираження у пацієнтів середнього, похилого і старечого віку, що можна розглядати як прояв сучасного клінічного патоморфозу депресій.

Ключові слова: депресивні розлади; психопатологічна симптоматика; опитувальник SCL-90-R.

\section{ВСТУП}

Проблема депресивних розладів є однією 3 найбільш складних і актуальних проблем у сучасній психіатрії [1-3]. Депресія супроводжується глибокими змінами у психічній сорері, високою суїцидальною активністю і порушеннями соціального функціонування хворих $[4,5]$. У ряді досліджень останніх років було доведено наявність патоморфозу депресивних розладів, прояви якого стосуються гендерних, вікових, соціальних характеристик хворих, а також клінічних проявів [6, 7]. У зв'язку з цим, вивчення сучасної клінічної френоменології депресивних розладів має важливе значення для визначення тенденцій і особливостей клінічного патоморфозу депресій; результати такого дослідження можуть бути використані для розробки сучасних методів прогнозування, лікування та профрілактики депресивних розладів [8, 9].

Метою дослідження було вивчити структуру і вираження психопатологічної симптоматики у хворих із депресивними розладами на сучасному етапі з урахуванням віку та гендерного фрактора.

\section{МАТЕРІАЛИ I МЕТОДИ}

3 дотриманням принципів біомедичної етики на підставі інорормованої згоди ми обстежили 245 хворих із депресивними розладами (107 чоловіків і 138 жінок), які зверталися за психіатричною допомогою до Вінницької обласної психоневрологічної лікарні імені акад. О. І. Ющенка, та за консультативно-лікувальною допомогою на кафедру медичної психології та психіатрії Вінницького національного медичного університету імені М. І. Пирогова протягом 2015-2019 рр. Критерієм включення у дослідження було встановлення діагнозу депресивного розладу відповідно до критеріїв МКX-10 (коди F 31.3, F 31.4, F 32.0, F 32.1, F 32.2, F 33.0, F 33.1, F 33.2). Середній вік обстежених хворих склав $(33,6 \pm 11,2)$ року (медіана - 33,0 роки, інтерквартильний діапазон - 22,0-42,0 роки), чоловіків

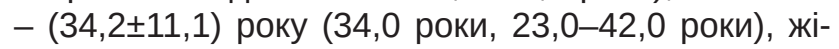
нок - $(33,2 \pm 11,4)$ року $(33,0$ роки, 22,0-41,0 роки), $\mathrm{p}>0,05$. Середня тривалість захворювання на момент обстеження була $(5,0 \pm 5,6)$ року $(4,0$ роки; 0,0-8,0 років), чоловіків - $(5,7 \pm 5,8)$ року $(4,0$ роки, 0,0-9,0 років), жінок - $(4,5 \pm 5,4)$ року $(2,0$ роки; 0,0-7,0 років), р>0,05. Усіх обстежених поділили на три групи залежно від віку на момент обстежен- senile patients, which can be seen as a manifestation of modern clinical pathomorphosis of depression.

Key words: depressive disorders; psychopathological symptoms; SCL-90-R questionnaire.

ня: до 30 років (89 осіб: 38 чоловіків і 51 жінка), 30-44 роки (99 осіб: 46 чоловіків і 53 жінки), та 45 років і старші (57 осіб: 23 чоловіки і 34 жінки). Обстеження проведено з використанням опитувальника вираження психопатологічної симптоматики Symptom Check List-90-Revised - SCL-90-R [10]. Оцінку характеру розподілу кількісних ознак проводи за допомогою тесту Шапіро - Уїлка. Міжгруповий аналіз розбіжностей виконували за допомогою непараметричного тесту Манна - Уїтні. Обробку даних здійснювали з використанням ліцензійного пакета прикладних програм Statistica 13. Прийнятним вважався рівень статистичної значущості розбіжностей у $95 \%(p<0,05)$.

\section{РЕЗУЛЬТАТИ Й ОБГОВОРЕННЯ}

Результати дослідження показали наявність у хворих із депресивними розладами широкого спектра психопатологічної симптоматики. Розподіл показників вираження психопатологічних симптомів за даними опитувальника SCL-90-R наведено у таблиці 1.

Як видно з таблиці, у чоловіків значуще ( $<<0,05$ і менше) вираженішими виявилися прояви депресії, ворожості й паранояльної симптоматики, тоді як у жінок - соматизації, обсесивно-компульсивної симптоматики, міжособистісної сензитивності, тривожності та фробічної тривожності. Соматизація при депресивних розладах $є$ переважно проявом соматофрормної афрективної симптоматики; в цілому чоловікам притаманний низький, а жінкам - близький до помірного рівень соматизації. Обсесивнокомпульсивна симптоматика у хворих на депресію переважно визначається афективною феноменологією і $є$ похідною від поведінкових проявів та когнітивних порушень; те ж стосується й фробічної тривожності. Рівні обсесивно-компульсивної симптоматики у чоловіків $€$ низькими, у жінок - помірними, фробічної тривожності у чоловіків низькими, а у жінок - близькими до помірного. Міжособистісна сензитивність, що проявляється почуттями особистісної неадекватності та неповноцінності, самозвинуваченням і відчуттям дискомфорту при міжособистісній взаємодії, є одним 3 проявів депресивного стану; тож закономірними $є$ доволі високі рівні міжособистісної сензитивності в обстежених пацієнтів. Депресія - найбільш виражений симптом у обстежених хворих; кількісні її значення відповідають підвищеному і високому рівням.
ISSN 2706-6282(print) ISSN 2706-6290(online)
Вісник медичних і біологічних досліджень Bulletin of Medical and Biological Research
$4(6), 2020$ 
Таблиця 1. Показники вираження психопатологічної симптоматики у чоловіків та жінок із депресивними розладами за даними опитувальника Symptom Check List-90-Revised (у балах)

\begin{tabular}{|c|c|c|c|c|}
\hline \multirow{2}{*}{ Симптом } & \multicolumn{3}{|c|}{ Значення показника, $\mathrm{M} \pm \mathrm{m} / \mathrm{Me}\left(\mathrm{Q}_{25}-\mathrm{Q}_{75}\right)$, бали } & \multirow{2}{*}{$\mathrm{p}$} \\
\hline & чоловіки & жінки & разом & \\
\hline Соматизація & $\begin{array}{c}0,82 \pm 0,21 / 0,80 \\
(0,70-0,80)\end{array}$ & $\begin{array}{c}1,24 \pm 0,59 / 1,00 \\
(0,80-1,50)\end{array}$ & $\begin{array}{c}1,05 \pm 0,51 / 0,80 \\
(0,80-1,20)\end{array}$ & 0,000 \\
\hline $\begin{array}{l}\text { Обсесивно-компульсивні } \\
\text { розлади }\end{array}$ & $\begin{array}{c}0,99 \pm 0,73 / 1,00 \\
(0,20-1,80)\end{array}$ & $\begin{array}{c}1,79 \pm 0,78 / 1,90 \\
(1,70-2,10)\end{array}$ & $\begin{array}{c}1,44 \pm 0,85 / 1,90 \\
(0,90-2,00)\end{array}$ & 0,000 \\
\hline Міжособистісна сензитивність & $\begin{array}{c}1,49 \pm 0,32 / 1,40 \\
(1,20-1,70)\end{array}$ & $\begin{array}{c}1,92 \pm 0,50 / 1,80 \\
(1,70-2,20)\end{array}$ & $\begin{array}{c}1,73 \pm 0,48 / 1,70 \\
(1,40-2,00)\end{array}$ & 0,000 \\
\hline Депресія & $\begin{array}{c}2,93 \pm 0,75 / 3,20 \\
(2,90-3,40)\end{array}$ & $\begin{array}{c}2,60 \pm 0,83 / 3,00 \\
(1,80-3,20)\end{array}$ & $\begin{array}{c}2,74 \pm 0,81 / 3,10 \\
(2,10-3,30)\end{array}$ & 0,000 \\
\hline Тривожність & $\begin{array}{c}2,17 \pm 0,35 / 2,20 \\
(1,90-2,40)\end{array}$ & $\begin{array}{c}2,58 \pm 0,43 / 2,60 \\
(2,40-2,90)\end{array}$ & $\begin{array}{c}2,40 \pm 0,45 / 2,40 \\
(2,10-2,70)\end{array}$ & 0,000 \\
\hline Ворожість & $\begin{array}{c}0,73 \pm 0,87 / 0,50 \\
(0,20-0,70)\end{array}$ & $\begin{array}{l}0,42 \pm 0,64 / 0,20 \\
(0,00-0,50)\end{array}$ & $\begin{array}{c}0,55 \pm 0,77 / 0,30 \\
(0,00-0,70)\end{array}$ & 0,000 \\
\hline Фобічна тривожність & $\begin{array}{c}0,75 \pm 0,28 / 0,70 \\
(0,60-0,90)\end{array}$ & $\begin{array}{c}1,19 \pm 0,49 / 1,10 \\
(0,90-1,40)\end{array}$ & $\begin{array}{c}1,00 \pm 0,47 / 0,90 \\
(0,70-1,30)\end{array}$ & 0,000 \\
\hline Паранояльні симптоми & $\begin{array}{c}0,28 \pm 0,15 / 0,20 \\
(0,20-0,30) \\
\end{array}$ & $\begin{array}{c}0,24 \pm 0,11 / 0,20 \\
(0,20-0,20) \\
\end{array}$ & $\begin{array}{c}0,26 \pm 0,13 / 0,20 \\
(0,20-0,20) \\
\end{array}$ & 0,000 \\
\hline Психотизм & $\begin{array}{c}0,67 \pm 0,24 / 0,70 \\
(0,50-0,90)\end{array}$ & $\begin{array}{c}0,62 \pm 0,23 / 0,60 \\
(0,50-0,80) \\
\end{array}$ & $\begin{array}{c}0,64 \pm 0,24 / 0,60 \\
(0,50-0,80) \\
\end{array}$ & 0,130 \\
\hline Додаткові симптоми & $\begin{array}{c}1,92 \pm 0,61 / 1,90 \\
(1,40-2,30)\end{array}$ & $\begin{array}{c}1,63 \pm 0,52 / 1,60 \\
(1,10-2,00)\end{array}$ & $\begin{array}{c}1,75 \pm 0,58 / 1,70 \\
(1,30-2,10)\end{array}$ & 0,000 \\
\hline Індекс GSI & $\begin{array}{c}1,38 \pm 0,38 / 1,40 \\
(1,10-1,60) \\
\end{array}$ & $\begin{array}{c}1,55 \pm 0,41 / 1,60 \\
(1,30-1,80)\end{array}$ & $\begin{array}{c}1,47 \pm 0,40 / 1,50 \\
(1,20-1,70) \\
\end{array}$ & 0,002 \\
\hline Індекс PST & $\begin{array}{c}49,19 \pm 10,09 / 50,00 \\
(41,00-55,00)\end{array}$ & $\begin{array}{c}53,96 \pm 9,22 / 55,00 \\
(49,00-59,00) \\
\end{array}$ & $\begin{array}{c}51,88 \pm 9,88 / 53,00 \\
(46,00-58,00) \\
\end{array}$ & 0,000 \\
\hline Індекс PDSI & $\begin{array}{c}2,49 \pm 0,26 / 2,50 \\
(2,30-2,70) \\
\end{array}$ & $\begin{array}{c}2,54 \pm 0,27 / 2,60 \\
(2,40-2,70) \\
\end{array}$ & $\begin{array}{c}2,52 \pm 0,27 / 2,50 \\
(2,30-2,70)\end{array}$ & 0,198 \\
\hline
\end{tabular}

Високі показники за шкалою тривожності виявляють симптоматику, асоційовану з високим рівнем маніфестованої тривожності, та когнітивні компоненти, що включають відчуття небезпеки, страху, побоювань і соматичні кореляти тривожності. Тривожність - друга за кількісними показниками після депресії шкала в обстеженого контингенту хворих, показники за цими шкалами є близькими. Ворожість є відображенням негативного афекту злості, дратівливості, обурення; ці прояви є характерними для дисороричної депресії; кількісне значення показника низьке. Паранояльна симптоматика у хворих на депресію виражена слабко, вона переважно відображує прояви ідей самоприниження і маячну інтерпретацію реальності крізь призму депресивних переживань. Прояви психотизму у хворих на депресію також виражені не суттєво, пацієнти негативно відповідали на питання шкали психотизму щодо галюцинаторних переживань та проявів деперсоналізації і психічних автоматизмів, але виявляли високі оцінки у питаннях, які стосувалися переживання почуття самотності та ідей гріховності й самозвинувачення, що є складовою клінічної картини депресії.

Загальний індекс тяжкості симптомів (Global Severity Index - GSI) € основним індикатором поточного стану пацієнта та глибини розладу; в обстежених він $є$ доволі високим, при цьому в жінок індекс тяжкості симптомів значуще $(p<0,01)$ вищий, ніж у чоловіків.

Загальний показник позитивних відповідей (Positive Symptom Total - PST), що виявляє кількість позитивних відповідей на питання тесту, в чоловіків незначно менший, а у жінок - дещо більший 50; при цьому гендерні розбіжності статистично значущі $(p<0,01)$.

Індекс наявного симптоматичного дистреcy (Positive Symptom Distress Index - PDSI), що $€$ мірою інтенсивності проявів, у обстежених хворих достатньо високий, у жінок він дещо вищий, порівняно з чоловіками, однак ці розбіжності статистично не значущі ( $>>0,05)$.

Аналіз вираження психопатологічної симптоматики з урахуванням віку хворих виявив загальну тенденцію до посилення вираження психопатологічної симптоматики з віком (табл. 2).

Загальна тенденція до прогредієнтності депресивного процесу проявляється у значущому ( $<<0,05$ і менше) погіршенні показників психопатологічної симптоматики у більш старших вікових групах порівняно з молодшими (за винятком психотизму, показники якого теж зростають, а де 
Таблиця 2. Показники вираження психопатологічної симптоматики у хворих із депресивними розладами різних вікових груп за даними опитувальника Symptom Check List-90-Revised (у балах)

\begin{tabular}{|c|c|c|c|c|c|c|}
\hline \multirow{2}{*}{ Симптом } & \multicolumn{3}{|c|}{ Значення показника, $\mathrm{M} \pm \mathrm{m} / \mathrm{Me}\left(\mathrm{Q}_{25}-\mathrm{Q}_{75}\right)$, бали } & \multicolumn{3}{|c|}{$\mathrm{p}$} \\
\hline & до 30 років & 30-44 роки & 45 років і старші & $1-2$ & $1-3$ & $2-3$ \\
\hline Соматизація & $\begin{array}{c}0,82 \pm 0,18 / 0,80 \\
(0,70-0,90)\end{array}$ & $\begin{array}{c}0,99 \pm 0,34 / 0,80 \\
(0,80-1,20)\end{array}$ & $\begin{array}{c}1,54 \pm 0,73 / 1,30 \\
(0,90-2,10)\end{array}$ & 0,002 & 0,000 & 0,000 \\
\hline $\begin{array}{l}\text { Обсесивно-компульсивні } \\
\text { розлади }\end{array}$ & $\begin{array}{c}1,13 \pm 0,71 / 1,00 \\
(0,70-1,90)\end{array}$ & $\begin{array}{c}1,43 \pm 0,80 / 1,90 \\
(0,90-2,00)\end{array}$ & $\begin{array}{c}1,93 \pm 0,93 / 2,00 \\
(1,90-2,50)\end{array}$ & 0,001 & 0,000 & 0,000 \\
\hline $\begin{array}{l}\text { Міжособистісна сензитив- } \\
\text { ність }\end{array}$ & $\begin{array}{c}1,51 \pm 0,31 / 1,60 \\
(1,30-1,80)\end{array}$ & $\begin{array}{c}1,70 \pm 0,40 / 1,70 \\
(1,40-2,00)\end{array}$ & $\begin{array}{l}2,12 \pm 0,59 / 2,20 \\
(1,80-2,60)\end{array}$ & 0,001 & 0,000 & 0,000 \\
\hline Депресія & $\begin{array}{c}2,45 \pm 0,79 / 2,80 \\
(1,80-3,10)\end{array}$ & $\begin{array}{c}2,77 \pm 0,80 / 3,10 \\
(2,50-3,30)\end{array}$ & $\begin{array}{c}3,16 \pm 0,67 / 3,40 \\
(3,20-3,60)\end{array}$ & 0,000 & 0,000 & 0,000 \\
\hline Тривожність & $\begin{array}{c}2,20 \pm 0,33 / 2,20 \\
(2,00-2,40)\end{array}$ & $\begin{array}{c}2,39 \pm 0,42 / 2,40 \\
(2,20-2,70)\end{array}$ & $\begin{array}{l}2,74 \pm 0,46 / 2,80 \\
(2,50-3,10)\end{array}$ & 0,000 & 0,000 & 0,000 \\
\hline Ворожість & $\begin{array}{c}0,22 \pm 0,25 / 0,00 \\
(0,00-0,50) \\
\end{array}$ & $\begin{array}{c}0,45 \pm 0,48 / 0,30 \\
(0,00-0,70) \\
\end{array}$ & $\begin{array}{c}1,26 \pm 1,16 / 0,70 \\
(0,50-2,50)\end{array}$ & 0,001 & 0,000 & 0,000 \\
\hline Фобічна тривожність & $\begin{array}{c}0,78 \pm 0,27 / 0,70 \\
(0,70-1,00) \\
\end{array}$ & $\begin{array}{c}0,95 \pm 0,39 / 0,90 \\
(0,70-1,30) \\
\end{array}$ & $\begin{array}{c}1,40 \pm 0,58 / 1,40 \\
(1,00-1,90)\end{array}$ & 0,001 & 0,000 & 0,000 \\
\hline Паранояльні симптоми & $\begin{array}{c}0,22 \pm 0,08 / 0,20 \\
(0,20-0,20) \\
\end{array}$ & $\begin{array}{c}0,26 \pm 0,13 / 0,20 \\
(0,20-0,20) \\
\end{array}$ & $\begin{array}{c}0,30 \pm 0,17 / 0,20 \\
(0,20-0,30) \\
\end{array}$ & 0,009 & 0,000 & 0,014 \\
\hline Психотизм & $\begin{array}{c}0,61 \pm 0,25 / 0,60 \\
(0,40-0,80) \\
\end{array}$ & $\begin{array}{c}0,64 \pm 0,24 / 0,60 \\
(0,50-0,80) \\
\end{array}$ & $\begin{array}{c}0,69 \pm 0,21 / 0,70 \\
(0,60-0,80) \\
\end{array}$ & 0,459 & 0,038 & 0,168 \\
\hline Додаткові симптоми & $\begin{array}{c}1,51 \pm 0,40 / 1,40 \\
(1,10-1,70)\end{array}$ & $\begin{array}{c}1,78 \pm 0,55 / 1,70 \\
(1,40-2,10) \\
\end{array}$ & $\begin{array}{c}2,10 \pm 0,67 / 2,10 \\
(1,60-2,60) \\
\end{array}$ & 0,000 & 0,000 & 0,005 \\
\hline Індекс GSI & $\begin{array}{c}1,26 \pm 0,26 / 1,30 \\
(1,10-1,40) \\
\end{array}$ & $\begin{array}{c}1,46 \pm 0,37 / 1,50 \\
(1,30-1,70)\end{array}$ & $\begin{array}{c}1,84 \pm 0,41 / 1,80 \\
(1,60-2,10)\end{array}$ & 0,000 & 0,000 & 0,000 \\
\hline Індекс PST & $\begin{array}{c}47,58 \pm 7,83 / 49,00 \\
(43,00-54,00) \\
\end{array}$ & $\begin{array}{c}51,49 \pm 9,30 / 54,00 \\
(46,00-58,00)\end{array}$ & $\begin{array}{c}59,25 \pm 9,61 / 60,00 \\
(56,00-65,00) \\
\end{array}$ & 0,000 & 0,000 & 0,000 \\
\hline Індекс PDSI & $\begin{array}{c}2,37 \pm 0,20 / 2,40 \\
(2,20-2,50) \\
\end{array}$ & $\begin{array}{c}2,50 \pm 0,23 / 2,60 \\
(2,30-2,70) \\
\end{array}$ & $\begin{array}{c}2,78 \pm 0,22 / 2,80 \\
(2,60-2,90) \\
\end{array}$ & 0,000 & 0,000 & 0,000 \\
\hline
\end{tabular}

статистично не значуще). При цьому збільшення показників у найстаршій віковій групі (45 років і старші), порівняно з групою 30-44 роки, більш суттєве, ніж збільшення показника у групі 30-44 роки порівняно $з$ наймолодшою віковою групою (до 30 років).

Одержані у нашому дослідженні дані в цілому підтверджують виявлену в дослідженнях останніх років тенденцію до клінічного патоморфозу депресивних розладів зі збільшенням поліморфнності клінічної симптоматики, зростанням у клінічній картині депресій тривожних і соматовегетативних проявів, а також патохарактерологічних змін.

При цьому виявлені гендерні відмінності можуть бути пояснені впливом різних психологічних статеворольових моделей поведінки, а також більшою тропністю жінок до тривожних, астенічних та соматизованих проявів депресій. Більш високі рівні депресії у чоловіків можуть бути пояснені, на наш погляд, загальною тенденцією до більш пізнього звернення чоловіків за психіатричною допомогою, зумовленою впливом чоловічого статеворольового патерну, і в цілому більш тяжкими проявами депресії у чоловіків при зверненні до психіатра. У жінок рівень тривожності (як при невротичних, так і при психотичних розладах) зазвичай є вищим, ніж у чо- ловіків, що також може бути пояснено гендерними відмінностями у психологічних і психопатологічних моделях реагування. Соматизація тісно асоційована з проявами тривоги; у хворих на депресію вона, на наш погляд, має переважно вторинний відносно тривоги характер, тож закономірно, більш виражені її рівні виявленні у жінок. Аналогічно, тісно пов'язані 3 тривожністю обсесивно-компульсивна симптоматика, міжособистісна сензитивність і фобічна тривожність. Натомість, у чоловіків виявлений більш високий рівень ворожості й паранояльної симптоматики, тісно пов'язаної з проявами депресії.

\section{ВИСНОВКИ}

Хворим із депресивними розладами притаманний широкий спектр психопатологічної симптоматики. Окрім власне депресивних проявів, для клініко-психопатологічної френоменології сучасних депресивних розладів характерні підвищені рівні тривожності, вираження якої $€$ зіставною 3 вираженням депресії, а також помірно виражені прояви міжособистісної сензитивності, обсесивно-компульсивної симптоматики та соматизації. Ці особливості можуть розглядати в якості ознак сучасного патоморфозу депресивних розладів. Ви- 
раження психопатологічної симптоматики при депресіях збільшується з віком пацієнта. У чоловіків більш вираженими є прояви депресії, ворожості та паранояльної симптоматики, а у жінок - тривожності, обсесивно-компульсивної симптоматики,

\section{СПИСОК ЛІТЕРАТУРИ}

1. The burden of depressive disorders in South Asia, 1990-2016: findings from the global burden of disease study / F. B. Ogbo, S. Mathsyaraja, R. K. Koti [et al.] // BMC Psychiatry. - 2018. - Vol. 18. - P. 333. - Access mode : https://doi.org/10.1186/s12888-018-1918-1.

2. Management of treatment-resistant depression in primary care: a mixed-methods study / N. Wiles, A. Taylor, N. Turner [et al.] // British Journal of General Practice. 2018. - Vol. 68 (675). - P. e673-e681. Access mode : https://doi.org/10.3399 / bjgp18X699053.

3. Prognosis and improved outcomes in major depression: a review / C. Kraus, B. Kadriu, R. Lanzenberger, C. A. Zarate, S. Kasper // Translational Psychiatry. - 2019. - 9. - P. 127. - Access mode : https://doi.org/10.1038 / s41398-019-0460-3.

4. Pshuk N. G. Introducing system of psychotherapeutic intervention for family caregivers of patients with endogenous mental disorders / N. G. Pshuk, L. V. Stukan, A. O. Kaminska // Wiadomosci Lekarskie. - 2018. - Vol. 71 (5). - P. 980-985. - Access mode : https://ncbi.nlm.nih.gov/ pubmed/30176626.

5. Recognition and treatment of cognitive dysfunction in major depressive disorder / H. Zuckerman, Z. Pan, C. Park [et al.] // Frontiers in Psychiatry. - 2018. - Vol. 9. - P. 655. - Access mode : https://doi.org/10.3389/fpsyt.2018.00655.

\section{REFERENCES}

1. Ogbo FA, Mathsyaraja S, Koti RK, Perz J, Page A. The burden of depressive disorders in South Asia, 19902016: findings from the global burden of disease study. BMC Psychiatry. 2018;18: 333. Available from: https://doi. org/10.1186/s12888-018-1918-1.

2. Wiles N, Taylor A, Turner N. Management of treatmentresistant depression in primary care: a mixed-methods study. British Journal of General Practice. 2018;68(675): e673-81. Available from: https://doi.org/10.3399 / bjgp18X699053

3. Kraus C, Kadriu B, Lanzenberger R, Zarate CA, Kasper S. Prognosis and improved outcomes in major depression: a review. Translational Psychiatry. 2019;9: 127. Available from: https://doi.org/10.1038/s41398-019-0460-3

4. Pshuk NG, Stukan LV, Kaminska AO. Introducing system of psychotherapeutic intervention for family caregivers of patients with endogenous mental disorders. Wiadomosci Lekarskie. 2018;71(5): 980-5. Available from: https://ncbi.nlm.nih.gov/pubmed/30176626.

5. Zuckerman H, Pan Z, Park C. Recognition and treatment of cognitive dysfunction in major depressive disorder. Frontiers in Psychiatry. 2018;9: 655. Available from: https://doi.org/10.3389/fpsyt.2018.00655. соматизації, міжособистісної сензитивності та фробічної тривожності. Виявлені закономірності повинні враховуватися при розробці діагностичних та лікувально-профрілактичних заходів для хворих із депресивними розладами.

6. McLachlan G. Treatment resistant depression: what are the options? / G. McLachlan // BMJ. - 2018. - Vol. 363. - P. k5354. - Access mode : https://doi.org/10.1136 / bmj. k5354

7. Belov O. O. Some trends of clinical and symptomatic pathomorphosis of depressive disorders taking into account the age factor / O. O. Belov, N. G. Pshuk // Wiadomości Lekarskie. - 2019. - Vol. 9(II). - P. 1786-1790. PMID: 31622267.

8. Al-Harbi KS. Treatment-resistant depression: therapeutic trends, challenges, and future directions / K.S. Al-Harbi // Patient Preference and Adherence. 2012. - Vol. 6. - P. 369-388. - Access mode : https://doi. org/10.2147/PPA.S29716.

9. Markova M. Contents and efficiency measures of psychoeducation in rehabilitation system of patients with bipolar affective disorder. Journal of Education / M. Markova, O. Rezunenko, H. Kozhyna // Health end Sport formerly Journal of Health Sciences. - 2017. - Vol. 7. - P. 711-715. - Access mode : https://doi.org/10.5281/zenodo.830020.

10. Derogatis L. R. Brief Symptom Inventory, and matching clinical rating scales. In M.E. Maruish (Ed.), The use of psychological testing for treatment planning and outcome assessment / L. R. Derogatis, L. Lazarus // Lawrence Erlbaum Associates, Inc. 1994. - P. 217-248.

6. McLachlan G. Treatment resistant depression: what are the options? BMJ. 2018;363: k5354. Available from: https://doi.org/10.1136 / bmj.k5354

7. Belov OO, Pshuk NG. Some trends of clinical and symptomatic pathomorphosis of depressive disorders taking into account the age factor. Wiadomości Lekarskie. 2019;9(II): 1786-90. PMID: 31622267.

8. Al-Harbi KS. Treatment-resistant depression: therapeutic trends, challenges, and future directions. Patient Preference and Adherence. 2012 6: 369-88. Available from: https://doi.org/10.2147/PPA.S29716.

9. Markova M, Rezunenko O, Kozhyna H. Contents and efficiency measures of psychoeducation in rehabilitation system of patients with bipolar affective disorder. Journal of Education, Health end Sport formerly Journal of Health Sciences. 2017;7: 711-5. Available from: https://doi.org/ 10.5281/zenodo.830020.

10. Derogatis LR, Lazarus L. Brief Symptom Inventory, and matching clinical rating scales. In M.E. Maruish (Ed.), The use of psychological testing for treatment planning and outcome assessment. Lawrence Erlbaum Associates, Inc. 1994. 